\title{
MARY IN THE ŠHIMO AND THE EARLY SYRIAC FATHERS
}

\author{
ROGER-YOUSSEF AKHRASS
}

\begin{abstract}
In this article, I examine the Old Testament roots and the patristic background of the Marian typology as it figures in the Šhimo, the service book for regular week day prayers in the West Syriac tradition. The focus is placed on two early Syriac Fathers: Ephrem (+373) and Jacob of Serugh (+521). The comparison reveals, first, that the Šhimo shares in common with Ephrem several Marian symbols: Eve, the Burning bush, the Ark of Covenant, the Staff of Aaron, the Fleece, the King's daughter, the Thirsty earth, the Veil enclosing water, and the Chariot of Eqekiel.; Secondly, that Jacob of Serugh introduced new types which were echoed in the Shimo: the Tent of Abrabam, the Tree bearing the lamb, the V eil of Moses, the new Well, the Sling of David, the new Pitcher of Elisha, the swift Cloud, the closed Door etc.; and, Thirdly, that the Šhimo has original Marian symbols unfound in Ephrem and Jacob of Serugh, like the Ladder of Jacob, the Tablets of the Law, the Jar of Manna, the Rock in the desert, the Candelabrum, the Locked garden, and sealed fountain. I also show, finally, how the condensed thought of Ephrem, was expanded and simplified with both Jacob of Serug and the Šhimo, within the context of Marian typology.
\end{abstract}




\section{INTRODUCTION}

In the West Syriac tradition, the Śbimo ${ }^{1}$ is the service book for regular weekday prayers which was compiled most likely at the end of the seventh century by Jacob of Edessa. ${ }^{2}$ In this book, the Mother of God is commemorated in numerous verse hymns and metrical texts, mostly anonymous, apart from a few verses explicitly ascribed to Ephrem, Jacob of Serugh, Balai,, and Simon the Potter. But when considering exclusively the works recognized by the scholars as authentically written by Ephrem the Syrian, one may be surprised to notice that the Shimo in use today in the Syriac Orthodox Church contains only one stanza dedicated for Mary that derives from the

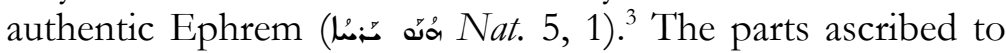

1 We are using in the current article the $4^{\text {th }}$ edition of the Shimo

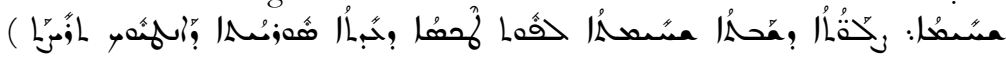

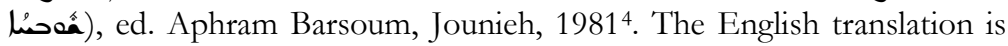
borrowed, when available, from Bede Griffiths, The Book of Common Prayer of the Syrian Church, Awsār Släwōtō 1. Kottayam, India: St. Ephrem Ecumenical Research Institute, 2017.

2 The manuscript tradition (British Library Add 14704; Paris syr. 150) attests that the services of the canonical hours of the ferial days were arranged by Jacob of Edessa (cf. William Wright, A Short History of Syriac Literature. London: A. and C. Black, 1894, p. 145-146; Ignatius Aphram I Barsoum, The Scattered Pearls. A History of Syriac Literature and Sciences, tr. Matti Moosa, New Jersey: Gorgias Press, $2003^{2}$, p. 59-60). The latest theological study on the Shimo by Menzer Habil accepts this assumption ("La théologie du salut selon le cycle hebdomadaire syro-antiochien. Étude historique et théologique", Villeneuve d'Ascq : Atelier national de reproduction des thèses, 2013, p. 27-34).

3 Here are the other Marian hymns of the Shimo attributed to Ephrem in Assemani and Lamy, and which are actually parts of anonymous madroshe:

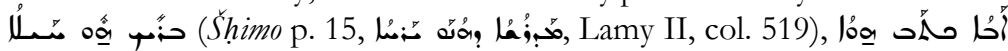

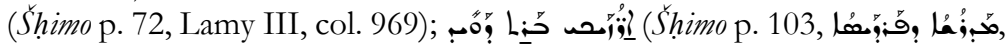

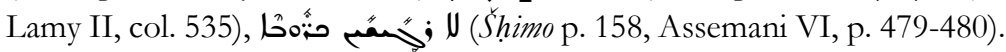

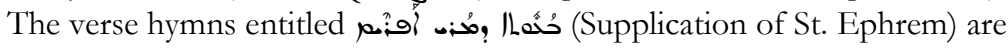
definitely not of him. 
Jacob of Serugh, on the other hand, seem to be more significant. ${ }^{4}$

Faithful in general to the tradition of the Syriac Fathers, these texts make great use of typology. In this paper, I suggest to study three texts of the Shimo containing different Old Testament prefigurations of Mary. This will lead us to demonstrate how the Syriac Liturgy, like Jacob of Serugh and Simon the Potter, has expanded and simplified Ephrem's condensed thought. The comparison of the Marian typology in the Śbimo with Ephrem and Jacob of Serugh will hopefully show, at least in part, how this compiled service book has embraced the earlier tradition and developed it. Results are summarized in three appendices: 1- Table of the Old Testament Marian symbols, used in the Šbimo with their parallel references in the Bible, Ephrem and Jacob of Serugh; 2- Table of particular Marian titles and epithets used in the Shrmo with their parallel occurrences in Ephrem and Jacob of Serugh; 3Marian verses attributed to Jacob of Serugh in the S̆himo lacking parallels in his published homilies.

\section{THE TENT OF ABRAHAM, THE TREE BEARING THE LAMB AND THE NEW WELL}

In a short paragraph of the Śhimo (p. 114), three symbols from the book of Genesis prefiguring Mary are mentioned:

"The glorious Tent of Abraham in which God entered and dwelt, as well as the tree bearing the lamb offered instead of Isaac, and the new well in the desert, depicted your figure." ${ }^{5}$

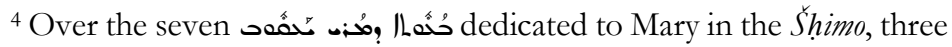
are extracted from the same homily 196 of Jacob of Serugh (Şhimo p. 16, 73-74, 90 = B VI, hom. 196, p. 3-4, 13, 14, 6-7 [615-616; 625-626; 618619]). The remaining supplications are unfound in the published homilies of Jacob (see Appendix 3).

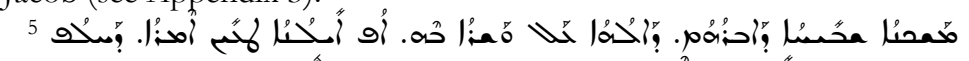

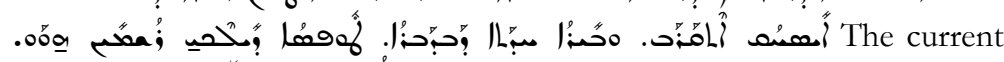

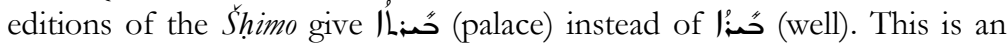
error to be corrected, for there is absolutely no biblical or patristic reference 
The three depictions of Mary found in the above mentioned stanza are all alien to Ephrem.

a) Although the most famous Syrian poet states that: "God dwelt in the tent of Abraham" (On Genesis 7, 4, CSCO 152, p. 65), he doesn't go further in comparing that tent with Mary. Jacob of Serugh, however, makes the step. He affirms that if somebody asks boldly how the womb of Mary was able to contain God, the answer is that it is easy for Him to dwell in the smallness, as He dwelt in the bush on Mount Sinai and in the tent of Abraham (cf. B III, hom. 94, p. 588). ${ }^{6}$

b) The second image is the tree bearing the ram ( $\mathrm{Gn} 22,13)$ which is a symbol of Mary giving birth to Christ. Another stanza of the Shimo refers to the same image in greater detail (p. 89)..$^{7}$ But according to Ephrem, the tree bearing the lamb is a symbol of the Cross only. ${ }^{8}$ The Marian typology here is

to a "new palace in the desert". Moreover, the same paragraph in the Fenqito (4rd General Sunday, 1st Qawmo d-lilyo) changes the last sentence from

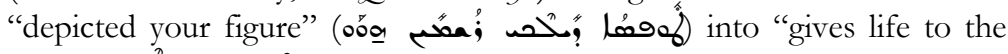

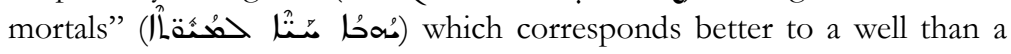
palace.

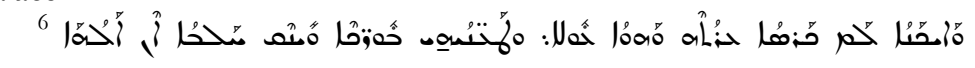

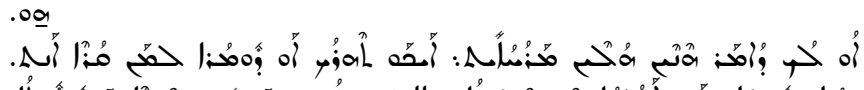

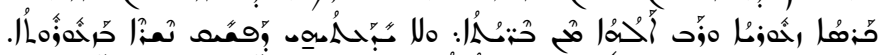

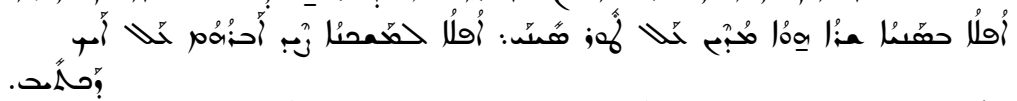

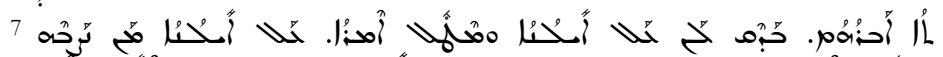

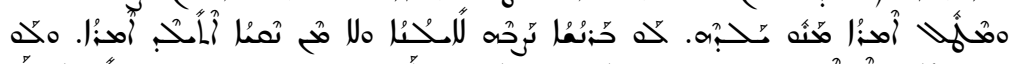

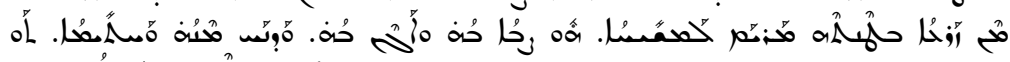

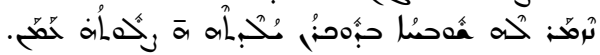

8 On Genesis 20, 3 (CSCO 152, p. 84); Sermones in Hebdomadem Sanctum II, 449-452 (CSCO 412, p. 16); Sogyata 3, 10 (CSCO 186, p. 204). This is against what S.P. Brock wrote: "Some of the 'types', however, are distinctive to the Syriac tradition: thus Mary as a 'tree' is based ultimately on Ephrem's Commentary on Gen. 22:13, where the ram 'held' in the tree (bush) is seen as a type of Christ, the Lamb, held in Mary's womb." (Sebastian P. Brock, "Mary," in Gorgias Encyclopedic Dictionary of the Syriac Heritage: Electronic Edition, edited by Sebastian P. Brock, Aaron M. Butts, 
apparently absent from his writings. Jacob of Serugh, on the other hand, expands the image and sees in the landscape of the Moriah, not only the death of Christ but also his miraculous birth: the ram born from the thicket without marriage is the image of Jesus' birth from the Virgin Mary; the offering of the ram represents the sacrifice of the Cross and the preservation of Isaac's life from death's corruption prefigures the resurrection of Christ (cf. B III, hom. 80, p. 311-312;' B IV, hom. 109, p. 102-103). In his third homily on Nativity, Jacob asserts:

"That tree which provided the ram on the mountain of Isaac

is the young girl who conceived the fruit in her womb without marital union.

The Well that came out in the wilderness for the world and it [world] drank

is the infant in whom the thirst of the peoples has been quenched." 10

(B VI, hom. 203, 184 [796])

c) This strophe brings us to the third image of the well in the desert, which refers to Num. 21:16-18. ${ }^{11}$ The well the

George A. Kiraz and Lucas Van Rompay, https://gedsh.bethmardutho.org/Mary).

${ }^{9}$ Konat suggests that Hom. 80 entitled "On the Mysteries, Types and Figures of Christ" is a compilation of verses from different homilies of Jacob, made probably by a redactor and not by the author himself, though the latter assumption cannot be omitted (see Johns Abraham Konat, "A Metrical Homily of Jacob of Serugh on the Mysteries, Types and Figures of Christ: Authentic or Compilation?”, Le Muséon 118:1-2 (2005), p. 72-73).

10 ET in Jacob of Sarug's Homilies on the Nativity, tr. Thomas Kollamparampil, New Jersey: Gorgias Press, 2010, Nat. III, lines 119-122, p. 200 (see also Nat. $I$, line 643, p. 82 = B VI, hom. 201, p. 138 [750]).

11 A well $(ح َ$ ) was there, the well of which the Lord said to Moses: Gather the people to me and I will give them water. At that time Israel sang this song, 'Come up, $\mathrm{O}$ well, sing to it. The well that the leaders dug, and the chiefs of the people excavated and searched it with their staffs.' From the wilderness it was given at Mattanah. (The Antioch Bible) 
nobles of the people dug with their rods and staffs, while the people were gathered and watching refers to the rock of the previous chapter Num. 20:8-11, which Moses struck with his staff. ${ }^{12}$ In the Pauline imagery, the rock is the Christ (1 Cor. 10:4). In the Pauline lineage, Jacob of Serugh identifies the rock hit by Moses's rod with Christ's side opened with the soldier's lance on the Cross (Jo 19:34). It is the well dug upon Golgotha from which the Living Waters flowed out (B I, hom. 18, p. 445;

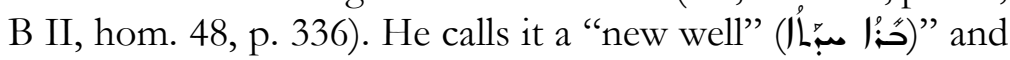
makes the connection with the above mentioned chapters of the book of Numbers (B II, hom. 53, p. 588-589; B III, hom. 95, p. 647-648).

But surprisingly, in a single couplet, Mary is assigned the title of "new well":

"Mary is the new well, whence flowed the Living Waters;

though unpierced, she gave birth to abundant streams for the thirsty."

(B VI, hom. 199, p. 91 [703])13

The discussion of the authenticity of the homily in question is beyond the limits of this paper. But it is worth noting the problem created by this imagery: in the case of Mary the well is unpierced, unlike the rock or the well of Moses and the Lord's side which are comparable by the mere fact that they

12 Take you a rod and gather the assembly, you and Aaron your brother. Speak unto the rock (صُمُْم) in their sight, so that it will give its water; bring our water from the rock and let the assembly and their beasts drink it. Moses took a staff from before the Lord as he commanded him. Moses and Aaron gathered all the assembly to the rock, and said to them: Hear now, you complainers! From this rock we shall bring out water for you. Moses raised his hand and hit the rock with his rod two times, and much water came out, and all the people drank, and their beasts. (The Antioch Bible).

${ }^{13}$ ET from S.P. Brock, "The Mysteries Hidden in the Side of Christ", Sobornost 7 (1978), p. 470. 
were both pierced. ${ }^{14}$ Yet, another stanza in the Šbimo tries to maintain that Mary is the rock of the desert, although Christ is actually the true Rock:

"The rock which brought forth streams in the desert was clearly a figure of you, holy virgin from whom came forth in the creation the Son of God, Who is the true rock, as Paul said." (Šbimo p. 165, ET p. 929)

Murray has showed that Ephrem is acquainted with the Jewish legend of the twelve streams giving drink to the twelve tribes, ${ }^{15}$ echoed also in the Śmo (p. 105). ${ }^{16}$ But in all his writings, this rock of Exodus - Numbers is always a type of Christ, and never of Mary. In Nat. 2,10, it is applied to Christ sending the Apostles:

"O Source untasted by Adam, which gave forth twelve speaking springs and Life filled the world!

${ }^{14}$ Peppard notes that the Bible reports encounters of women at wells. Jacob, Isaac, and Moses found their wives at wells. When Jesus met the Samaritan woman at a well (John 4), marriage was a topic of discussion. Thus, whenever in the Bible a man and a woman meet at a water source, a bride may be found, be she real or spiritual only (Michael Peppard, The World's Oldest Church: Bible, Art and Ritual at Dura-Europos, Syria, New Haven, Conn: Yale University Press, 2016, p. 191). Following this biblical tradition, Syriac iconography represents the Virgin Mary receiving the announcement about her pregnancy at a wellspring. The Annunciation scenes in many Syriac manuscripts include a well with water or a vessel containing water, such as a pitcher beside the Virgin who receives the Holy Spirit in the form of water. In the Rabbula Gospels, Mary listens to the angel's words, while water flows from a fountain or well into the vessel beside her. In the $13^{\text {th }}$ century icons, the well is placed between Mary and the angel Gabriel (cf. Lamia Doumato, "Book Review of Peppard, The World's Oldest Church...", Syriac Orthodox Patriarchal Journal 55, 2017, p. 86-87).

${ }^{15}$ Robert Murray, Symbols of Church and Kingdom: A Study in Early Syriac Tradition, London / New York: Cambridge University Press, 1975, p. 209210. Murray explains that this tradition was attached to the Rock already by the second century $\mathrm{BC}$, but in its developed form seems to combine Elim (Ex. 15: 27) with the well of Be'er (Num. 21:16-18), and finally makes all one with the miraculous travelling well of Miriam.

16 "... there are twelve springs which flowed in the desert..." 
Jesus, who was called 'Rock'

was represented as a type in the midst of the rock, [to show] that through the twelve Apostles

he gives the 'Medicine of Life' to the whole world to drink."

In summary, neither Ephrem nor Jacob of Serugh applies to Mary the image of the rock. The latter states clearly: "The rock that gave birth to rivers for the great people is Christ who supplied life to the dead world." ${ }^{\prime 17}$

\section{THE BUSH, THE ARK, THE FLEECE AND THE LADDER}

The Saturday Vespers in the Šbimo gives a concise stanza which contains four Marian symbols:

"Moses likened you to the bush and David, your father, to the ark, Gideon figured you by the fleece and Jacob the just by the ladder, by which the race of man has been raised up to heaven." (Šbimo p. 150, ET p. 859)

a) The typological application of the burning bush (Ex 3,2) to Mary's womb, abundantly attested in the Shbimo (p. 5, 28, 54, $83,88,150,176,180-181,183,189)$, is found in some works not certainly attributed to Ephrem. ${ }^{18}$ But in the $\mathrm{V}^{\text {th }}-\mathrm{VI}^{\text {th }}$ century, the image became familiar to Jacob of Serugh who explained it extensively in his great Homily on Faith (cf. B III, hom. 94, p. 588-589).

b) The Ark of the Covenant with its contents resembles Mary. In the ark were the jar of Manna and the tables of the Law; in Mary were the bread of life and the Word of God (Śbimo p. 65, 69, 89, 180). Also, the jar of the Manna and the

${ }^{17}$ B VI, Hom. 203, p. 183 [795], ET in Jacob of Sarug's Homilies on the Nativity, op. cit., Nat. III, lines 111-112, p. 198. See also Hom. 80, p. 307.

${ }^{18}$ Cf. Commentary on the Diatessaron I, 25; Sermo II, 13-16 (CSCO 363, p.39) ET by S.P. Brock "Homily on the Nativity" in, The Harp of the Spirit, Poems of Saint Ephrem the Syrian, Cambridge: The Institute for Orthodox Christian Studies, 2013³ , p. 91. 
tables themselves are symbols of Mary because they embrace symbols of Christ: the Manna (bread) and the word of God (Ibid.). Furthermore, the staff of Aaron which budded within the holy of holies is taken as a figure of the Virgin Mary who brought forth Christ without intercourse with man (Ibid., and p. 183).

Ephrem compares Mary to the Ark only in regard to the Word of God dwelling in her (cf. Nat. 4, 113; 16, 16). He calls

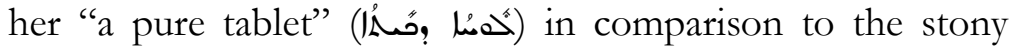
tablets of the Law (Nat.16,17). He refers also to the staff of Aaron:

"The staff of Aaron sprouted, and the dry wood brought forth;

his symbol has been explained today-it is the virgin womb that gave birth."

(Nat. 1, 17)

Ephrem doesn't seem to use the jar of Manna as a Marian symbol. This is also the case for Jacob of Serugh, who compares David leaping and dancing before the ark (2 Sam. 6: 14-16) with John leaping in the womb of his mother Elizabeth in front of Mary (B VI, hom. 198, p. 58-59 [670-671] cf. also B VI, hom. 197, p. 37 [649]). This comparison explains why the Shlmo stanza quoted above says about Mary: "David your father likened you to the ark". Moreover, Jacob states that Aaron's staff which sprouted leaves without watering pictured the womb which carried the fruit without marriage (B III, hom. 80, p. 314, Hom 93, p. 565, B VI, hom. 201, p. 138 [750]). According to Jacob, the two tablets are figures of the two testaments (B I, hom. 25, p. 593-594). No Marian typology is evoked in this regard.

c) In the writings of Ephrem, there is at least one certain reference to the fleece of Gideon (Jud. 6:36-40) as a symbol of the Virgin Mary" ${ }^{19}$ " One depicted His descent by the rain

19 The fleece of Gideon symbolizes also the teaching of the Christ (Virg. 8, 17) and the baptism (Epiph. 7, 14). 
descending gently, and represented Mary by the magnificent and pure fleece." When speaking about the fleece, Jacob combines the symbolism of Mary and the baptism found separately in Ephrem (B III, hom. 80, p. 312-313, ${ }^{21}$ see also B VI, hom. 203, 183 [795]).

d) The ladder of Jacob (Gen. 28:12) is a Christological symbol present in the background of Joh 1: 51. In the Shimo, it represents, on one hand, the Church (p. 116), and on the other hand, the Virgin May by whom the humans were raised up to heaven (p. 150, 176, 180). For Ephrem, Christ revealed himself to Jacob through the ladder (Sog. III, 8). For Jacob of Serugh, the ladder is an image of the Cross (B III, hom. 74, p. 196-197; B V, hom. 166, p. 475) and the crucified himself (B V, hom. 179, p. 710). The Marian typology is absent in both writers' works.

\section{THE VEIL}

a) In a particular image of the Śhimo, Mary is called "veil of the godhead (ILْớ Moses" (p. 64-65, ET p. 465). Both Mary and the veil covering the shining face of Moses (Exod. 34:33-35) concealed something from the Godhead. This comparison, unknown to Ephrem, is marvelously developed by Jacob of Serugh, in his Homily on the veil of Moses:

That hidden child who did not loose the seals of virginity at his birth

loosened the veil of prophecy at his crucifixion.

Joy of heart did he provide to both prophecy and virginity,

for at his birth and at his crucifixion the two of them shone out:

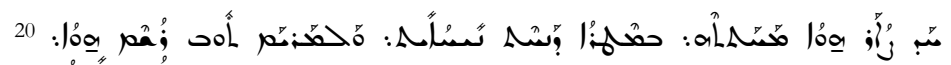

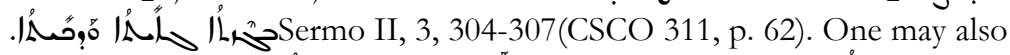
mention Sog. I, 16: :

21 ET by Konat, "A Metrical Homily", op. cit., p. 79-80. 
for virginity he preserved intact, that she might not be laid bare, while prophecy's face he uncovered, that she might not be veiled.

Since his birth did not tear that veil of virginity, on his cross he tore off that covering from prophecy. He preserved youth in the ranks of virginity, while he lightened the burden that old age was carrying. The young Mary continued on in her virginity, while the aged Moses cast off the covering that proved heavy.

The virgin rejoiced that he had preserved her virginity, the prophet too rejoiced that he had removed from him the veil.

He left virginity's beauty preserved untouched, He revealed prophecy's beauty that had been covered up.

Moses leaps with Joy for he has revealed his beauty that had been veiled;

Mary exults for her virginity has not been harmed.

The girl and the aged man both have gained their true beauty

through the Son of God who himself is the beauty of all beautiful things.

The great prophet bore him on his face beneath the veil,

Mary bore him within the gates of her virginity.

At his birth he left the seals unbroken,

at his crucifixion he removed the veils from the prophets.

He revealed their words, and the earth was illumined at their revelation; 
their symbols shone out and all now possess their explanation. ${ }^{22}$

(B III, hom. 79, p. 300-301)

b) But another couplet attributed in the Šbimo to Jacob of Serugh describes Mary as a veil, in a different sense:

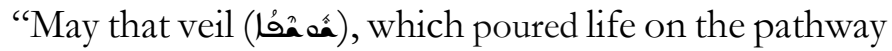
of the world,

make intercession and offer our prayers before God." (p. 104, ET p. 379)

The couplet is not found in the so far published homilies of the bishop of Serugh. But it has resonances in his writings, rooted in the Bible, specifically in Prov. 30: 4:

"Who has gone up to heaven and come down? Who has gathered up the wind in the palms of his hands?

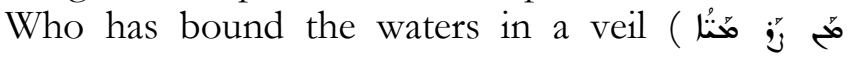

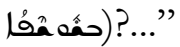

The veil referred to here is the clouds, as confirmed by a parallel verse Job 26:8 "He has bound the waters in His clouds

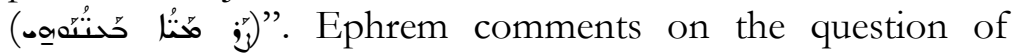
Salomon and applies it to both the Eucharist and Mary, making reference also to the veil that covers the offerings and the altar, and the tradition of taking the Eucharist in veiled hands:

"[14] 'Who has ever grasped the wind in his hands?' Come and see, Solomon, what your father's Lord (Ps 110:1) has done!

Fire and Spirit, against their nature, he has mingled and poured into his disciples' hands.

[15] Who has ever bound the waters in a veil?” (

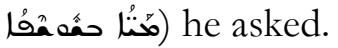

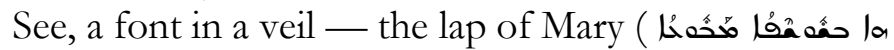

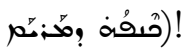

${ }^{22}$ ET by Sebastian P. Brock, Jacob of Sarug's Homily on the Veil on Moses' Face. Texts from Christian Late Antiquity 20, Homilies of Mar Jacob of Sarug 1. Piscataway, NJ: Gorgias Press, 2009, p. 50-52. 


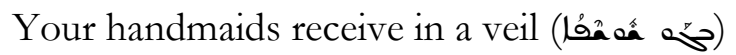

From the Cup of Life, a drop of life (

[16] See, Power concealed in the veil of the sanctuary, a power which no mind has ever conceived.

His love bent down, descended, and hovered over the veil on the altar of reconciliation." (Fid. 10,1416) 23

The Fire and Spirit are in the lap of Mary and in the Bread and the Cup (Fid. 10,17). The veil is Mary's lap which is compared to a cloud containing a font - Christ, and distilling life to the world. The veil also covers the altar, the Cup of Life, and the hands of the women receiving the communion.

This constellation of symbols is repeated more plainly by Jacob of Serugh on different occasions. Like Ephrem, Jacob rephrases the question of Prov. 30:4: "Who has ever seen the Spirit hold in the palms, or a veil in which waters are bound?" This happened, answered Jacob, in the incarnation which was completely unexpected because nobody has ever hoped to see and touch God who is Spirit:

"The ear heard and the eye saw and the hands held the Spirit in the palms and the Living Waters in the veil. The Fire is placed on the fingers of humans, And they turn it over without being burned by the flame.

Behold, the Living Waters are in the holy Veil - Mary who was bound up and sealed in virginity.

The Holy Spirit dwelt in the bread and it became Body, And behold, the humans are holding the Glorious (Spirit) in the palms.

The Fire and the Spirit are being eaten and drunk.

${ }^{23}$ ET by Robert Murray, "A Hymn of St. Ephrem to Christ on the Incarnation, the Holy Spirit, and the Sacraments", Eastern Churches Review 3, 1970, p. 144. [translation modified] 
This is something new that no one has ever imagined."'24

(B IV, hom. 133, p. 743-745) 25

The detailed interpretation given by Jacob of Serugh, inspired by some condensed words of Hymn 10 on Faith of Ephrem, reveals a rhetorical difference between the two Syrian poets. It is about writing intensely or extensively. The power of Ephrem's poetry is in its concise phrasing joined to a highly suggestive imagery, whereas the style of Jacob reflects his prolixity dictated by his concern to instruct and entertain, through a clear discourse, the audience sitting and listening to

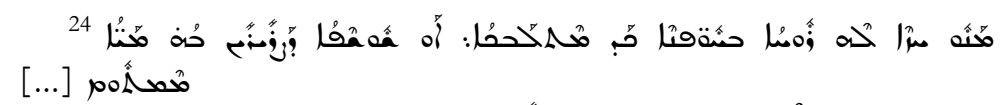

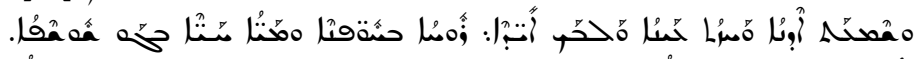

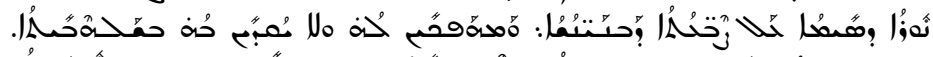

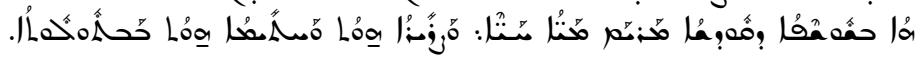

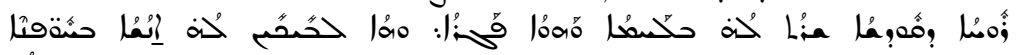

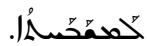

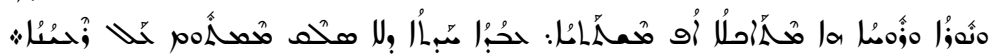

25 "Who is the one who grasped the wind/Spirit in his cupped hands unless here,

for Fire and Spirit are grasped in the palms of hands and in swaddling clothes?

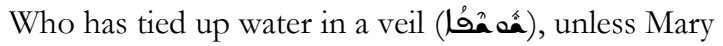

who in her virginity, conceived the child who is wholly a marvel?

The young virgin carried the Living Water in the womb,

and it became a wonder that had never happened in the world, apart from it.

O King Solomon, come, see that your parable has been explained by Him, and sing praise to the Lord of your father, if you can.

The wind has been grasped in the palms and in the fingers

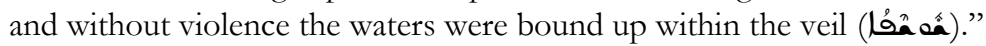

(Nat. III, lines 153-162, p. 204 = B VI, hom. 203, p. 185-187 [797-798])

"That- "who bound the water in the veil"- why it was said, but because of the bosom of Mary which multiplied life.

If you look, who held the wind/Spirit in His hand, behold, inside the palms (there is) fire and Spirit, for he who takes Him." (B III, hom. 80, p. 314, ET Konat, "A Metrical Homily", op. cit., p. 81 ; see also B II, Hom. 43, p. 236) 
him for long hours. The prayers of the Šbimo follow Jacob’s strategy and simplify the condensed ephremian thought, making it more accessible to the simple worshippers.

\section{THE SIMPLIFICATION OF EPHREM'S THOUgHT IN THE S̆HIMO}

Even though only one single stanza in the S̆himo derives from the genuine Ephrem (cf. introduction), the book is imbued with ephremian thought. The following examples will hopefully show how Liturgy tries to make the ephremian legacy more accessible, by elucidating its allusive style.

a) Towards the disputants who pretend to know everything about God, His son and His deeds, Ephrem expresses his basic embarrassment to find an appropriate name for Jesus (Nat. 6, 1-2). The same applies for Jesus' mother:

"Our Lord, no one knows how to address Your mother.

[If] one calls her "virgin," her child stands up, and "married"- no one knew her [sexually].

But if Your mother is incomprehensible, who is capable of [comprehending] You?” (Nat.11, 1) ${ }^{26}$

This idea expressed by Ephrem in 23 words is reformulated twice in the Śhimo, once in the meter of فم مُ (attributed to Simon the Potter) with 42 words (p. 15), ${ }^{27}$ and again in the

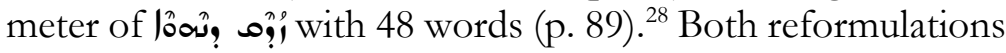

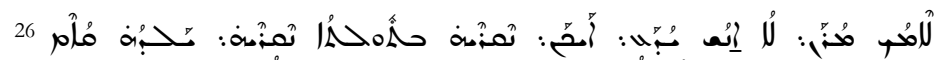

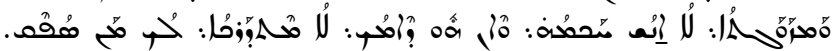

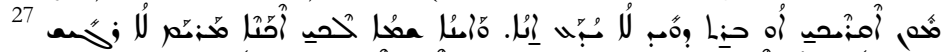

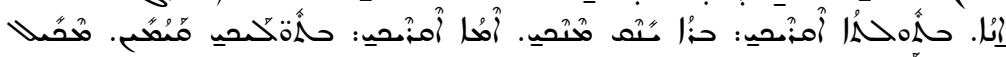

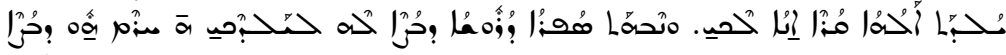
a)

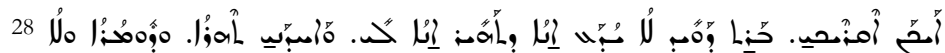

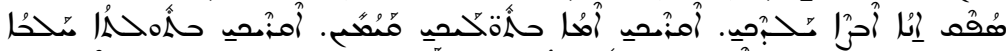

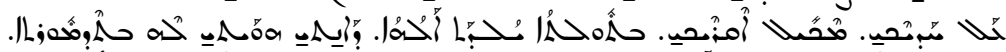

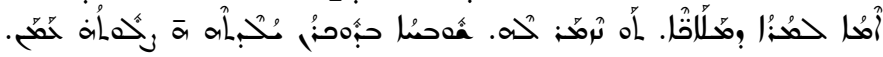


lack the last and most important contrast in Ephrem's stanza (if Your mother is incomprehensible, who is capable of [comprehending] You?). Here is the translation of the first text:

"How to call you, I know not, daughter of David; and what name to give you, Mary, I cannot tell. If I call you virgin, I see a son who sucks at your breast; if I call you mother, your virginity remains; therefore I will call you mother of God, that the learned may be put to shame and the disputant who would question your child $(\omega ? \sim \sim \sim)$, halleluia, cursed be he who would investigate Him.” (ET, p. 231)

b) In another example, Ephrem compares two miraculous births: Eve born from Adam and Jesus from Mary. He says:

"The man (Adam) who never gives birth, bore Eve the mother:

how much more should Eve's daughter (Mary) be believed to have borne a child without [the aid of] a man!"29 (Nat. 1, 15)

It is striking that two modern translations of this paragraph

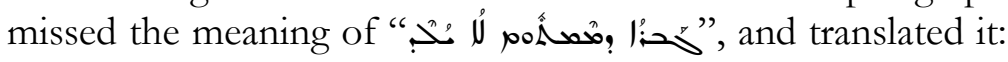
"the man who never was born" (McVey), ", "A man (Adam) who himself knew no birth" (Brock). ${ }^{31}$ This is quite

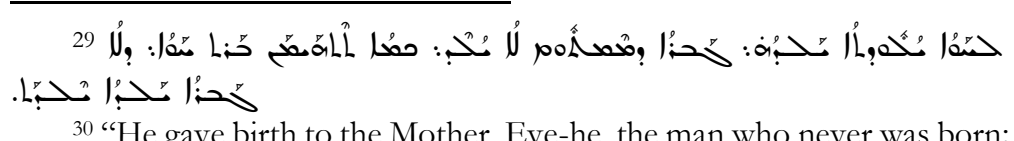

30 "He gave birth to the Mother, Eve-he, the man who never was born; how worthy of faith is the daughter of Eve, who without a man bore a child!" (Kathleen Elizabeth McVey, Ephrem the Syrian. Hymns on the Nativity, Hymns Against Julian, Hymns on Virginity and on the Symbols of the Lord. The Classics of Western Spirituality. New York / Mahwah: Paulist Press, 1989, p. 65)

31 "A man (Adam) who himself knew no birth, bore Eve the mother: how much more should Eve's daughter (Mary) be believed to have given birth without the aid of a man!" (Sebastian P. Brock, "Mary in Syriac Tradition", in Mary's Place in Christian Dialogue: Occasional Papers of the Ecumenical Society of the Blessed Virgin Mary, 1970-1980. Edited by Stacpoole, Alberic. Slough: St. Paul's Publications, 1982, p. 187). 
understandable because Ephrem's elusive style makes often his ideas difficult to grasp at first glance - and sometimes after multiple readings. Therefore, Jacob of Serugh elucidates as usual the condensed thought of Ephrem and puts it in a developed paragraph, of which I quote only a few couplets:

"You admit that a man gave birth to a woman and you have no difficulty,

and you do not believe that Mary, in a virginal way, gave birth...

Adam, a man gave birth to a woman and there is no doubt,

and Mary, a woman, since she gave birth to child, there is controversy...

If you are an unbeliever, take the two (away) from your teaching, and admit to me that neither Adam nor Mary gave birth.

It is unjust that you believe the begetting through man, and you falsely accuse the woman that she is corrupted as a result of her birthing.

The way of her having a child is abandoned but not that of a man (Adam);

grant to her that generation of man in her virginity.

When Eve came forth, there was no breach in the integral nature, and how here, in the coming forth of the child are there many breaches?"

(B VI, hom. 199, 92- 93 [704-705]) ${ }^{32}$

The same idea is found in a hymn of the Śbimo composed in the meter of

${ }^{32}$ ET by James Puthuparambil, Mariological Thought of Mar Jacob of Serugh, Moran 'Eth'o 25, SEERI, Kottayam, 2005, p. xviii.

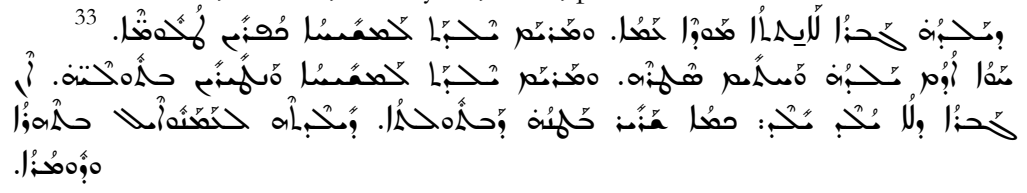


"The [Jewish] people admit that the man (Adam) gave birth to the woman (Eve). But the unbelieving deny that Mary gave birth to Christ. Adam gave birth to Eve while his side remained sealed, and Mary gave birth to Christ while her virginity was preserved. If the man who does not give birth, did give birth, how much more true is the conception of the Virgin who gave birth to Emmanuel, miraculously and marvelously." (Š ḩimo p. 47)

One can see again how the Śbimo is explaining in 33 words what Ephrem had expressed in 15 words only, and Jacob of Serug in a long paragraph of 273 words.

In his long letter to Rabban Yeshu', a Syrian monk fascinated by the Greek rituals, who criticized the simplicity of the Syriac prayers, Bar Salibi reveals that the Ś himo service book was prepared to be chanted by the simple worshippers and nuns. Therefore its compilers chose simple verses which would immediately be assimilated by the mind and would stimulate the heart to repentance:

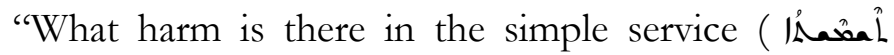
(مشّمصنا), that you are despising? It contains "multum

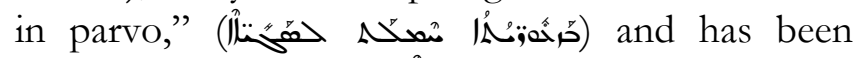
arranged for the weak (مشتّن), and at one time, for the nuns. Now that it has been established everywhere, you see that it carries significance and substance about all the essential topics: the Mother of God, the Apostles, the Fathers, the Prophets, the Martyrs, repentance, and the dead." 34

\section{CONCLUSION}

Concerning the Old Testament typology, Ephrem was likely the first Syrian poet to point out the following Marian symbols: Eve, the Burning bush, the Ark of Covenant, the Staff of

34 Alphonse Mingana, Woodbrooke Studies, 1 (1927), p. 34 [Text p. 74] translation modified. 
Aaron, the Fleece, the King's daughter, the Thirsty earth, the Veil enclosing water, and the Chariot of Ezekiel. To this list, Jacob of Serugh added the Tent of Abraham, the Tree bearing the lamb, the Veil of Moses, the new Well, the Sling of David, the new Pitcher of Elisha, the swift Cloud, the closed Door, and titles with biblical resonances like City, Ship and Dove. With the Śmo, more original images and titles were adduced: the Ladder of Jacob, the Tablets of the Law, the Jar of Manna, the Rock in the desert, the Candelabrum, the Locked garden, and sealed fountain etc. (see Appendices 1-2). The study of this evolution must be complemented by a comparison with the Hymni de Maria published by Lamy (II, col. 517-642). Nevertheless, it is interesting to note how some images applied initially by Ephrem to the Cross (tree bearing the lamb, ladder of Jacob), or to the Christ (dove, light, rock), became later with Jacob of Serugh and the Sthimo, Marian symbols, particularly in the مَّزّما (Cantus ad Magnificat), most of which are translated from Greek antiphons. ${ }^{35}$ Unfortunately, in these hymns, the Virgin receives some Christological titles such as "Light of those sitting in the darkness" (p. 186), "Wonder" (p. 181) and "the Ladder of Jacob" (p. 176, 180).

Anyway, this study has shown that the theological style of Jacob's metrical homilies and especially of Ephrem's didactic hymns (مص:قa) didn't lend itself to liturgical use. Liturgy had to adapt the legacy of the early great theologians and poets by two means: first, by adding devotional material (praise, intercession etc.) and second, by simplifying Ephrem's condensed poetry, in spite of the loss that such attempt might cause. It seems that in various fields, the Syrians liked to keep two parallel tracks: just like they had a common and simple version of the Bible (Pritto), along with the Syro-hexaplar version reserved to scholars, they sought also to have a simple and light collection

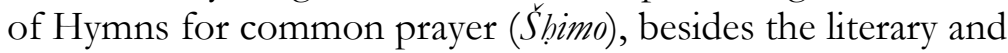
weighty corpus of Ephrem's didactic hymns (م, (م:a).

35 Dom Jules Jeannin, Mélodies liturgiques Syriennes et Chaldéennes, vol. 2, Paris : Leroux, 1928, p. 23. 


\section{Abbreviations}

A I-II = Akhrass, Roger-Youssef and Syryany, Imad, eds. 160 Unpublished Homilies of Jacob of Serugh. Damascus: Syriac Orthodox Patriarchate, 2017.

Assemani VI = Stefanus Evodius Assemani, ed. Sancti patris nostri Ephraem Syri opera omnia qua exstant, Grace, Syriace, Latine. Tomus tertius: Syriace et latine, Roma: Typographia Pontificia Vaticana, 1743.

B I-VI = Paulus Bedjan, ed. Homiliae Selectae Mar Jacobi Sarugensis, Paris - Lipsiae, t. I, 1905 (hom. 133); t. II, 1906 (hom. 33-70); t. III, 1907 (hom. 71-107); t. IV, 1908 (hom. 108-146); t. V, 1910 (hom. 147-195), Piscataway NJ, t. VI, 2006 (hom. 196-211).

c.

$=$ couplet

CSCO = Corpus Scriptorum Christianorum Orientalium

Fid. $\quad=$ de Fide (Hymns on Faith, CSCO 154).

Epiph. = de Epiphania (on Epiphany, CSCO 186)

hom. = homily

Lamy I-IV = T. J. Lamy, Sancti Ephraem Syri bymni et sermones, 4 vol., Malines 1882-1902.

Nat. $\quad=$ de Nativitate (On the Nativity, CSCO 186)

$\mathrm{PO} \quad=$ Patrologia Orientalis

Sog. $\quad=$ Sogyata $($ CSCO 186)

Virg. $\quad=$ de Virginitate (On Virginity, CSCO 223) 


\section{APPENDIX 1}

Table of the Old Testament Marian symbols, used in the Śbimo with their parallel references in the Bible, Ephrem and Jacob of Serugh.

\begin{tabular}{|c|c|c|c|}
\hline Šḥimo & Bible & Ephrem & $\begin{array}{l}\text { Jacob of } \\
\text { Serugh }\end{array}$ \\
\hline $\begin{array}{l}\text { Eve } \\
\text { lo. } \\
\text { (p. 48) }\end{array}$ & $\begin{array}{l}\text { Cf. Gen. } \\
\text { 3:20; 4:1; } \\
\text { 2Co 11:3; } 1 \\
\text { Tim. 2:13 }\end{array}$ & $\begin{array}{l}\text { Nat. } 2,7 ; 4,111- \\
112 ; 17,4 ; \\
22,31 ; \text { Virg. 37, } \\
1 ; \text { Ecc. 35;46, } \\
11-13 ; 47,1 ; 49, \\
7 \text {-Diat. 2, 2 etc. }\end{array}$ & $\begin{array}{l}\text { B VI, hom. } \\
\text { 196, p. 4, } \\
\text { 15-23 [616, } \\
627-635]\end{array}$ \\
\hline 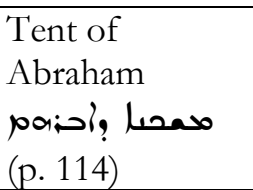 & $\begin{array}{l}\text { Gen. 18:1- } \\
10\end{array}$ & - & $\begin{array}{l}\text { B III, hom. } \\
94 \text {, p. } 588\end{array}$ \\
\hline $\begin{array}{l}\text { Tree bearing } \\
\text { the lamb } \\
\text { أححا لهم (p. 89;114) }\end{array}$ & Gen. 22:13 & - & $\begin{array}{l}\text { B III, hom. } \\
\text { 80, p. 311- } \\
\text { 312; B IV, } \\
\text { hom. 109, } \\
\text { p. 102-103; } \\
\text { B VI, hom. } \\
\text { 201, p. } 138 \\
\text { [750] and } \\
\text { hom. 203, } \\
184 \text { [796] }\end{array}$ \\
\hline $\begin{array}{l}\text { Ladder of Jacob } \\
\text { I محح } \\
\text { (p. 150; 176; } \\
180)\end{array}$ & Gn 28:12 & - & -21 \\
\hline $\begin{array}{l}\text { Bush } \\
\text { مس } \\
\text { (p. 5; 54; 83; 88; } \\
\text { 150; 176; 180; } \\
181 ; 183 ; 189)\end{array}$ & Exod. 3:2 & $\begin{array}{l}\text { Diat. I, 25; } \\
\text { Sermo II, 13-16 } \\
\text { (CSCO 363, } \\
\text { p.39). } \\
\text { (authenticity?) }\end{array}$ & $\begin{array}{l}\text { B III, hom. } \\
94, \text { p. } 588- \\
589\end{array}$ \\
\hline
\end{tabular}




\begin{tabular}{|c|c|c|c|}
\hline $\begin{array}{l}\text { Jar of Manna } \\
\text { ممسل ومسا (p. } 65 ; 69 ; 180) \\
\text { (p. }\end{array}$ & $\begin{array}{l}\text { Exod. 16: } \\
\text { 33; Heb. } \\
9: 4\end{array}$ & - & - \\
\hline $\begin{array}{l}\text { Rock in the } \\
\text { desert } \\
\text { صاوا ح:حز } 1 \text { مال } \\
\text { (p. 165) }\end{array}$ & $\begin{array}{l}\text { Exod. 17: } \\
1-6\end{array}$ & - & - \\
\hline $\begin{array}{l}\text { Tablets of the } \\
\text { Law } \\
\text { حقما وبمهما } \\
\text { (p. 88-89; 180) }\end{array}$ & $\begin{array}{l}\text { Exod. } \\
25: 16\end{array}$ & $\begin{array}{l}\text { لهما وحهlet" } \\
\text { "Pure tablet" } \\
\text { Nat.16,17 }\end{array}$ & - \\
\hline $\begin{array}{l}\text { Candelabrum } \\
\text { مسن: } \\
\text { (p. } 180^{2} \text { in } \\
\text { Mawrbo) }\end{array}$ & $\begin{array}{l}\text { Ex 25:31- } \\
40 ; 37: 17- \\
29 ; \text { Num. } \\
8: 1-4\end{array}$ & - & $\begin{array}{l} \\
\text { > love of } \\
\text { God (B I, } \\
\text { hom. 26, p. } \\
621) ; \\
\text { Cross in } \\
\text { the Church } \\
\text { (B V, hom. } \\
173, \text { p. } 600)\end{array}$ \\
\hline $\begin{array}{l}\text { Veil of the } \\
\text { Godhead } \\
\text { ILoditg lanea } \\
\text { (p. 64-65) }\end{array}$ & $\begin{array}{l}\text { Ex 34:33- } \\
35\end{array}$ & - & $\begin{array}{l}\text { B III, hom. } \\
\text { 79, p. 300- } \\
301\end{array}$ \\
\hline $\begin{array}{l}\text { Staff of Aaron } \\
\text { o;ai, of a a } \\
\text { (p. 65; 69;180; } \\
\text { 183) }\end{array}$ & Num. 17 & Nat. 1,17 & $\begin{array}{l}\text { B III, hom. } \\
\text { 80, p. 314, } \\
\text { Hom 93, p. } \\
\text { 565, B VI, } \\
\text { hom. 201, } \\
\text { p. } 138 \text { [750] }\end{array}$ \\
\hline $\begin{array}{l}\text { New well } \\
\text { حن: مبـا" } \\
\text { (p. 114) }\end{array}$ & $\begin{array}{l}\text { Num. 20:8- } \\
11 ; 21: 16- \\
18\end{array}$ & 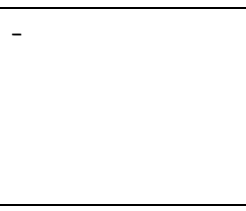 & $\begin{array}{l}\text { Christic title } \\
\text { except in B } \\
\text { VI, hom. } \\
199, \text { p. } 91 \\
{[703]}\end{array}$ \\
\hline $\begin{array}{l}\text { Fleece } \\
\text { IL- } \\
\text { (p. 69; 180;181) }\end{array}$ & $\begin{array}{l}\text { Jud. 6:36- } \\
\text { 40; Ps. 72:6 }\end{array}$ & $\begin{array}{l}\text { Sermo II, 3, } \\
\text { 304-307 (CSCO } \\
\text { 311, p. 62); Sog. } \\
\text { I, } 16\end{array}$ & $\begin{array}{l}\text { B III, hom. } \\
\text { 80, p. 312- } \\
\text { 313; B VI, }\end{array}$ \\
\hline
\end{tabular}




\begin{tabular}{|c|c|c|c|}
\hline & & & $\begin{array}{l}\text { hom. 203, } \\
183 \text { [795] }\end{array}$ \\
\hline $\begin{array}{l}\text { Sling of David } \\
\text { محدا } \\
\text { (p. 147) }\end{array}$ & $\begin{array}{l}1 \mathrm{Sam} . \\
17: 40\end{array}$ & - & $\begin{array}{l}\text { B II, hom. } \\
34 \text {, p. } 64\end{array}$ \\
\hline $\begin{array}{l}\text { Ark } \\
\text { Los } \\
\text { (p. 65, 69, 89, } \\
180)\end{array}$ & $\begin{array}{l}2 \text { Sam. } \\
\text { 6:14-16 }\end{array}$ & $\begin{array}{l}\text { Nat. 4, 113;12, } \\
2 ; 16,16\end{array}$ & $\begin{array}{l}\text { B VI, hom. } \\
\text { 197, p. } 37 \\
\text { [649]; hom. } \\
\text { 198, p. 58- } \\
59 \text { [670- } \\
671]\end{array}$ \\
\hline 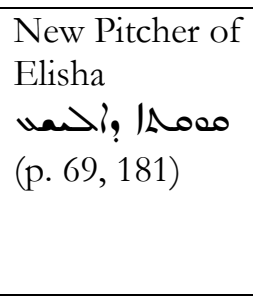 & $\begin{array}{l}2 \text { Kings } \\
2: 19-22\end{array}$ & Cf. Epiph. 8:22 & $\begin{array}{l}\text { B IV, hom. } \\
\text { 116, p. } 263- \\
\text { 264; hom. } \\
\text { 144, p. } 903 \text {; } \\
\text { B VI, hom. } \\
\text { 203, p. } 183 \\
\text { [795] }\end{array}$ \\
\hline $\begin{array}{l}\text { King's daughter } \\
\text { حنا محصا } \\
\text { (p. } 67,86)\end{array}$ & $\begin{array}{l}\text { Ps. 45:9-16; } \\
\text { cf. Exod. } \\
\text { 2:5-10 }\end{array}$ & $\begin{array}{l}\text { Nat. 5, } 21 \\
\text {, Church (Sermo } \\
\text { II, 3, CSCO } \\
\text { 311, p. 63, 75, } \\
\text { 77) }\end{array}$ & $\begin{array}{l}\text { A II, hom. } \\
\text { 73, c. 188- } \\
190 \\
\text { ' Church (B } \\
\text { I, hom. 22, } \\
\text { p. 538; B II, } \\
\text { hom. 34, p. } \\
\text { 45; B III, } \\
\text { hom. 74, p. } \\
\text { 203; A II, } \\
\text { hom. 74, c. } \\
347-348 \text { ) }\end{array}$ \\
\hline $\begin{array}{l}\text { Thirsty earth } \\
\text { INa, Air } \\
\text { (p. 47) }\end{array}$ & $\begin{array}{l}\text { Ps. 63:1; } \\
\text { 72:6; Isa. } \\
\text { 53:2 }\end{array}$ & $\begin{array}{l}\text { Nat. 1, 11; 4, 84; } \\
\text { 9, 4; 18, 13; 26, } \\
\text { 6; Sermo II, 3, } \\
\text { 304-307 (CSCO } \\
\text { 311, p. 62); (cf. } \\
\text { Fid. 12, 10) }\end{array}$ & $\begin{array}{l}\text { B II, hom. } \\
\text { 51, p. 424; B } \\
\text { V, hom. 163, } \\
\text { p. 399, 403; } \\
\text { B VI, hom. } \\
\text { 203, p. } 188 \\
\text { [800] }\end{array}$ \\
\hline $\begin{array}{l}\text { City } \\
\text { م:بهi } \\
\text { (p. 73) } \\
\end{array}$ & $\begin{array}{l}\text { Ps 72:16 } \\
\text { (cf. Ps 60:9; } \\
\text { 108:10) }\end{array}$ & - & $\begin{array}{l}\text { Cf. B V, } \\
\text { hom. 163, p. } \\
\text { 399; مبرى }\end{array}$ \\
\hline
\end{tabular}




\begin{tabular}{|c|c|c|c|}
\hline & & & $\begin{array}{l}\text { lool B VI, } \\
\text { hom. 201, p. } \\
135 \text { [747] }\end{array}$ \\
\hline $\begin{array}{l}\text { Veil } \\
\text { farca } \\
\text { (p. 104) }\end{array}$ & Prov. 30:4 & Fid. 10:14-15 & $\begin{array}{l}\text { B II, hom. } \\
\text { 43, p. 236; } \\
\text { B III, hom. } \\
\text { 80, p. 314; } \\
\text { B IV, hom. } \\
\text { 133, p. 743- } \\
\text { 745; B VI, } \\
\text { hom. 203, p. } \\
\text { 185-187 } \\
\text { [797-798]; A } \\
\text { I, 9, c. 154; } \\
\text { 13, c. 114- } \\
\text { 115; }\end{array}$ \\
\hline $\begin{array}{l}\text { Ship } \\
\text { الحفا } \\
\text { (p. 5, 16,47,84, } \\
96,123)\end{array}$ & $\begin{array}{l}\text { Cf. Prov. } \\
31: 14\end{array}$ & - & 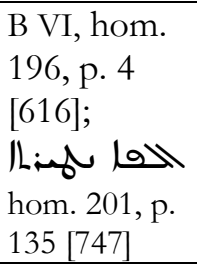 \\
\hline $\begin{array}{l}\text { Dove } \\
\text { Lo } \\
\text { (p. 48) }\end{array}$ & Cf. Cant 6:9 & $\begin{array}{l}\text { - Christ (Nat. 26, } \\
\text { 8) }\end{array}$ & $\begin{array}{l}\text { B VI, hom. } \\
201, \text { p. } 116, \\
130,135,147 \\
{[728,742,} \\
747,759]\end{array}$ \\
\hline 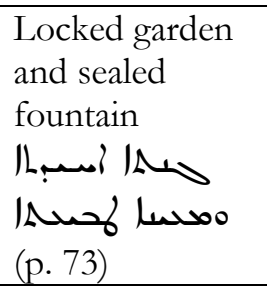 & Cant 4:12 & - & - \\
\hline $\begin{array}{l}\text { Swift Cloud } \\
\text { Iسل مخحل } \\
\text { (p. 54, 64, 69, } \\
\text { 180) }\end{array}$ & Isa. 19:1 & 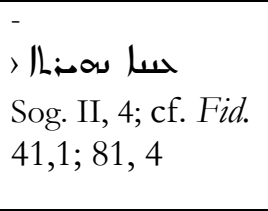 & $\begin{array}{l}\text { B VI, hom. } \\
\text { 201, p. } 130 \\
\text { [742]; hom. } \\
\text { 203, p. } 183 \\
\text { [795] }\end{array}$ \\
\hline $\begin{array}{l}\text { Chariot } \\
\text { مد:مح| }\end{array}$ & $\begin{array}{l}\text { Ezek. 1:4- } \\
28\end{array}$ & $\begin{array}{l}\text { Sog. I, 44; III, } 4 \\
\text { Cf. Nat. 18, } 5\end{array}$ & $\begin{array}{l}\text { B VI, hom. } \\
\text { 196, p. } 4\end{array}$ \\
\hline
\end{tabular}




\begin{tabular}{|c|c|c|c|}
\hline $\begin{array}{l}\text { (p. 15, 38, 40, } \\
65,73,142 \\
158,183)\end{array}$ & & & $\begin{array}{l}\text { [616]; hom. } \\
\text { 197, p. } 43 \\
\text { [655]; hom. } \\
\text { 198, p. 52, } \\
65 \text { [664, } \\
677] ; \text { hom. } \\
\text { 199, p. } 82 \\
\text { [694]; hom. } \\
\text { 201, p. } 109- \\
\text { 110, 128, } \\
\text { 132, 154 } \\
\text { [721-722, } \\
740,744, \\
766], \text { hom. } \\
203, \text { p. } 181 \text {, } \\
\text { 190 [793, } \\
802] \text { etc. }\end{array}$ \\
\hline 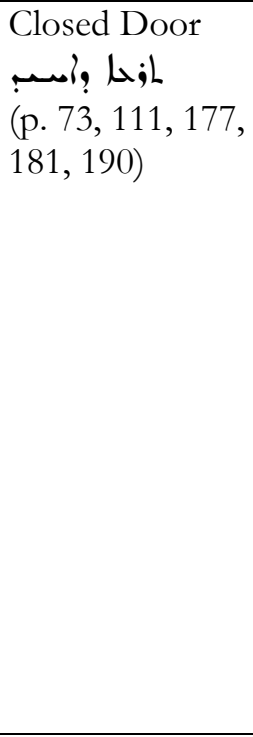 & $\begin{array}{l}\text { Ezek. 44: 1- } \\
2\end{array}$ & - & $\begin{array}{l}\text { B III, hom. } \\
\text { 80, p. 314; } \\
\text { hom. 94, p. } \\
\text { 584; B V, } \\
\text { hom. 164, } \\
\text { p. 436; B } \\
\text { VI, hom. } \\
\text { 196, p. } 4 \\
\text { [616]; hom. } \\
\text { 199, p. 83, } \\
\text { 89 [695, } \\
\text { 701]; hom. } \\
\text { 203, p. 183 } \\
\text { [795]; } \\
\text { Against Jens, } \\
\text { 6 (PO 38/1, } \\
\text { p. 168). }\end{array}$ \\
\hline
\end{tabular}




\section{APPENDIX 2}

Table of particular Marian titles and epithets used in the Stbimo with their parallel occurrences in Ephrem and Jacob of Serugh

\begin{tabular}{|c|c|c|}
\hline Titles, epithets & Ephrem & Jacob of Serugh \\
\hline 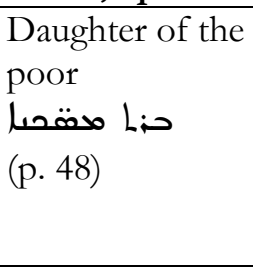 & Sog. II, 2 & $\begin{array}{l}\text { B I, Hom. 6, p. 128; B VI, } \\
\text { hom. 196, p. 4, } 14 \text { [616, } \\
\text { 626]; hom. 198, p. } 55 \text { [667]; } \\
\text { hom. 199, p. } 81 \text { [693]; } \\
\text { hom. 201, } 110 \text { [722]; A I, 1, } \\
\text { c. } 25\end{array}$ \\
\hline $\begin{array}{l}\text { Prophetess } \\
\text { (p. 48) } \\
\text { (p. }\end{array}$ & Diat. 2, 6 & - \\
\hline 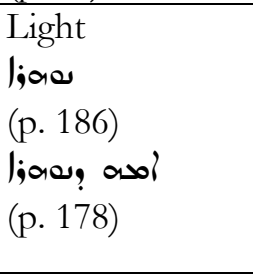 & $\begin{array}{l}\text { Christic title; } \\
\text { Mary is the eye } \\
\text { or the earth } \\
\text { which receives } \\
\text { the light. }\end{array}$ & $\begin{array}{l}\text { Christic title; } \\
\text { Mary is the Mother of the } \\
\text { Light } \\
\text { l;ad, Lor } \\
\text { B VI, hom. 197, p. } 37 \\
\text { [649]; }\end{array}$ \\
\hline $\begin{array}{l}\text { East } \\
\text { مب:سا } \\
\text { (p. 48) }\end{array}$ & - & $\begin{array}{l}\text { B III, hom 93, p. 566; B } \\
\text { VI, hom. 198, p. 56-57 } \\
\text { [668-669] }\end{array}$ \\
\hline $\begin{array}{l}\text { Second heaven } \\
\text { chilg l. } \\
\text { (p. 16, 64, 68, } \\
87,130,158)\end{array}$ & $\begin{array}{l}\text { Cf. Fid. } 81,4 ; \\
\text { Nat. 23,11; } \\
\text { Sog. II, 10-11 }\end{array}$ & $\begin{array}{l}\text { B VI, hom. 196, p. } 3 \text { [615]; } \\
\text { hom. 198, p. 51-54 [663- } \\
\text { 666]; Ih محسا hom. 201, } \\
\text { p. } 132 \text { [744] }\end{array}$ \\
\hline 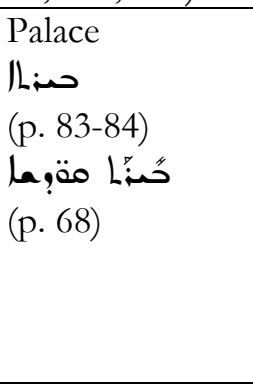 & 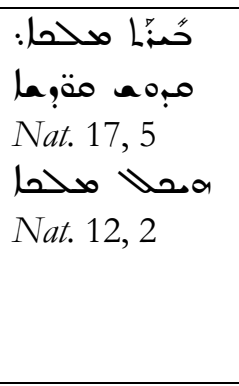 & 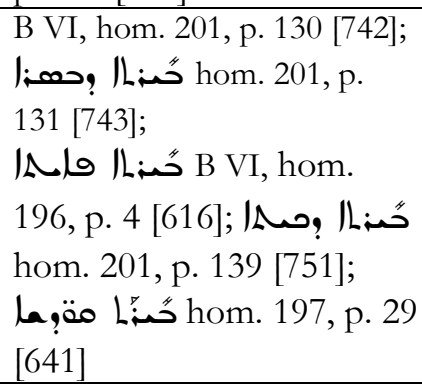 \\
\hline $\begin{array}{l}\text { Dwelling of the } \\
\text { Most High }\end{array}$ & - & ILodig IN a a \\
\hline
\end{tabular}




\begin{tabular}{|c|c|c|}
\hline $\begin{array}{l}\text { محس| ومن:مها } \\
\text { (p. 150) }\end{array}$ & & 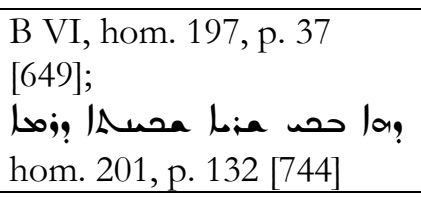 \\
\hline $\begin{array}{l}\text { Glorious throne } \\
\text { Lلـ mosil } \\
\text { (p. 183) }\end{array}$ & - & 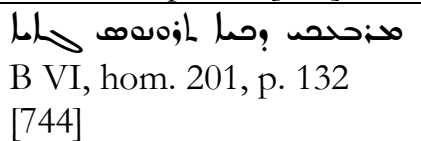 \\
\hline 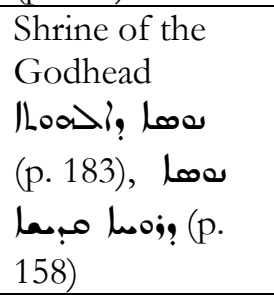 & $\begin{array}{l}\text { حـ مسمن: } \\
\text { Diat. 2, } 6\end{array}$ & $\begin{array}{l}\text { lo p } \\
\text { B VI, hom. 196, p. 9, } 26 \\
\text { [621, 638]; hom. 201, p. } \\
\text { 126-127 [738-739] }\end{array}$ \\
\hline $\begin{array}{l}\text { Holy } \\
\text { Storehouse } \\
\text { اa,gor joi } \\
\text { (p. 180) }\end{array}$ & - & 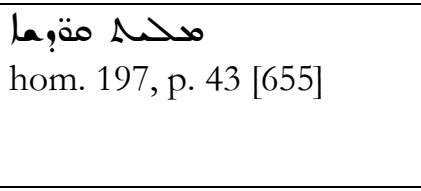 \\
\hline 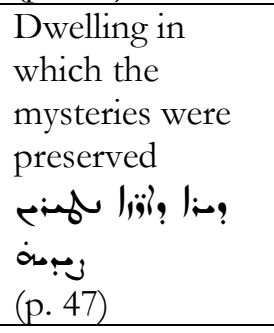 & $\begin{array}{l}\text { - Christ is l } \\
\text { liä? (Fid. 9,12) }\end{array}$ & 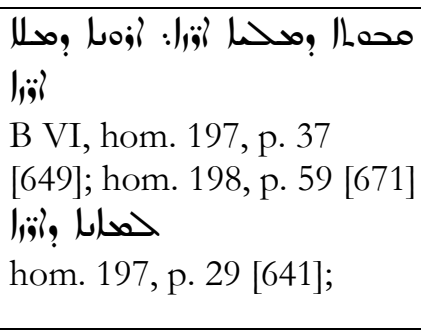 \\
\hline 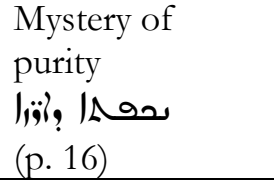 & - & 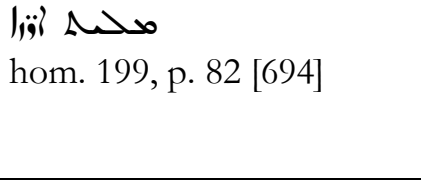 \\
\hline 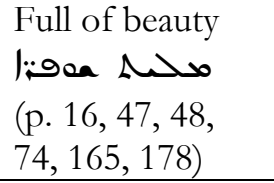 & ' & $\begin{array}{l}\text { B VI, hom. 196, p. } 4-5 \\
\text { [616-617]; hom. 197, p. } 29 \\
\text { [641] etc. }\end{array}$ \\
\hline $\begin{array}{l}\text { Veil which is } \\
\text { spread over the } \\
\text { creation } \\
\text { حas Who }\end{array}$ & - & - \\
\hline
\end{tabular}




\begin{tabular}{|c|c|c|}
\hline $\begin{array}{l}\text { (p. 47) } \\
\text { See Veil above }\end{array}$ & & \\
\hline $\begin{array}{l}\text { Pearl } \\
\text { م: 30, 69) }\end{array}$ & $\begin{array}{l}\text { Her virginity: } \\
\text { Nat. } 12,7\end{array}$ & $\begin{array}{l}\text { Her virginity: B VI, hom. } \\
\text { 201, p. 135-136 [747-748] }\end{array}$ \\
\hline 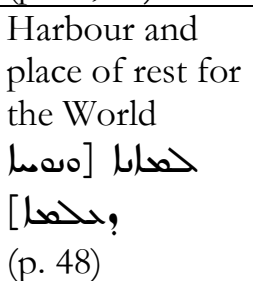 & $\begin{array}{l}\text { Nat. 9, 4; } \\
\text { Christic title } \\
\text { (Nat. 19, 18) }\end{array}$ & 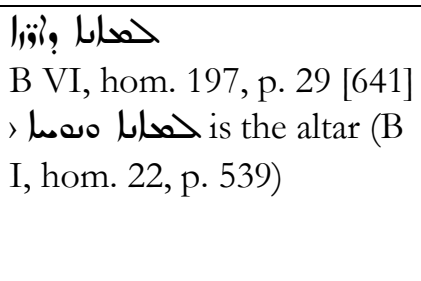 \\
\hline $\begin{array}{l}\text { Letter } \\
\text { containing our } \\
\text { prayers } \\
\text { lLir } \\
\text { (p. } 168)\end{array}$ & - & 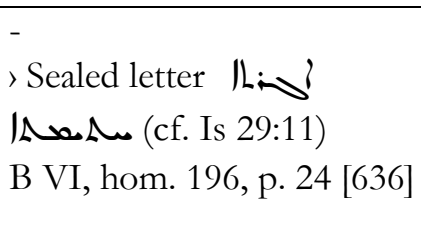 \\
\hline $\begin{array}{l}\text { Vine } \\
\text { I p. 167) }\end{array}$ & $\begin{array}{l}\text { INa, INo } \\
\text { Nat. } 8,8\end{array}$ & $\begin{array}{l}\text { IN_oN } \mathbf{I N \infty} \\
\text { B VI, hom. 198, p. } 55 \\
\text { [667]; hom. 201, p. } 119 \\
\text { [731]; hom. 203, p. } 192 \\
\text { [804] }\end{array}$ \\
\hline
\end{tabular}




\section{APPENDIX 3}

Marian verses attributed to Jacob of Serugh in the Śbimo, without parallels in his published homilies

Ṣ̌̉imo, p. 16

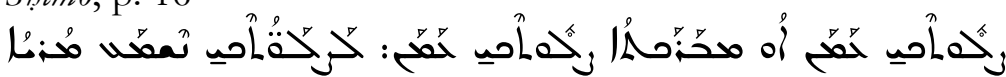
> $>$ خ

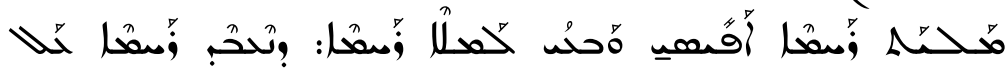

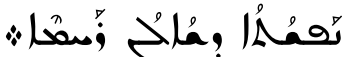

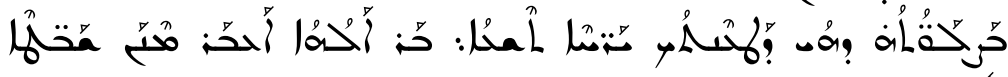
$\star \star \star x$

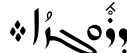

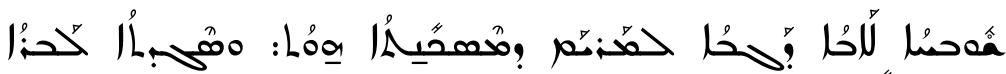

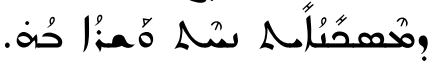

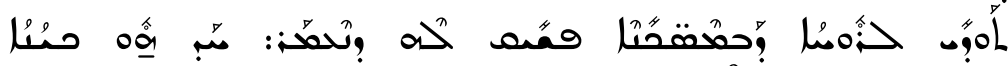
要 $\star \star \star$

Ş̌̉imo, p. 74

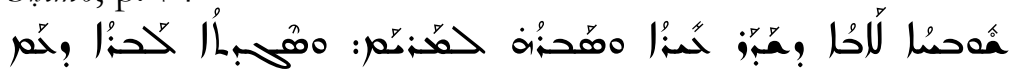

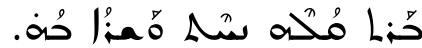

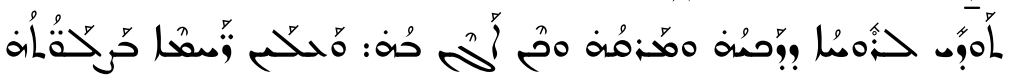
$\star \star \star$

Šhtimo, p; 90

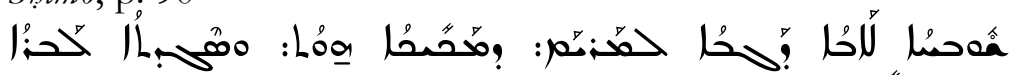

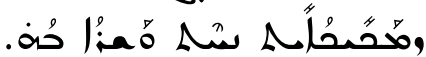

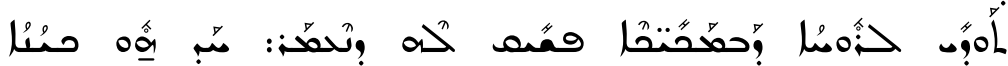
* $\star \star \star$

Šḅimo, p. 47-48 


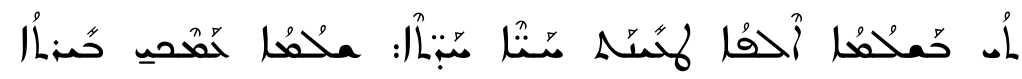

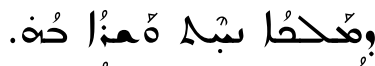

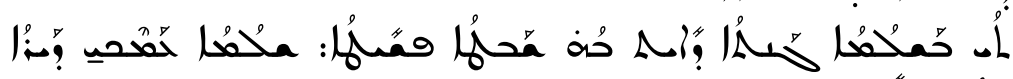

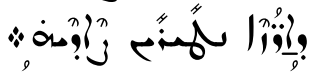

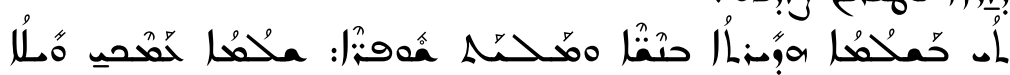

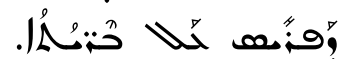

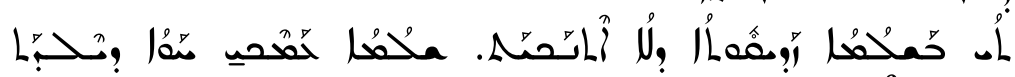

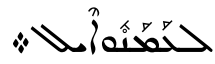

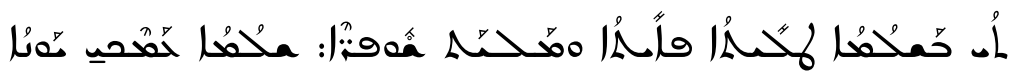

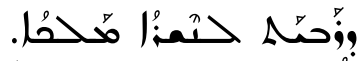

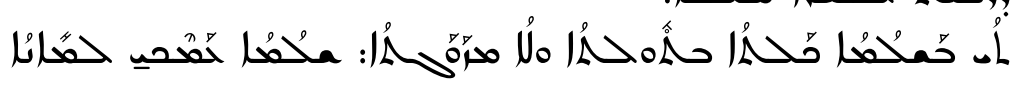

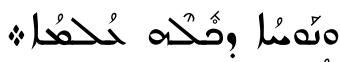

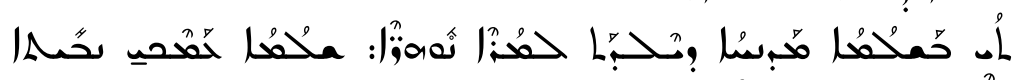

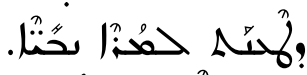

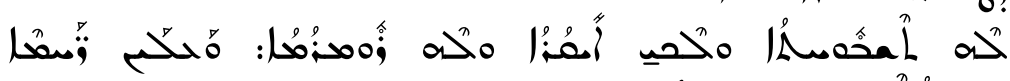
$\star \star \star$

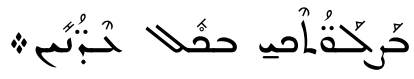

Šḩimo, p. 104

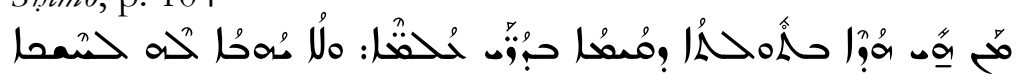

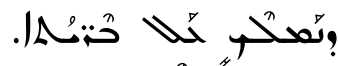

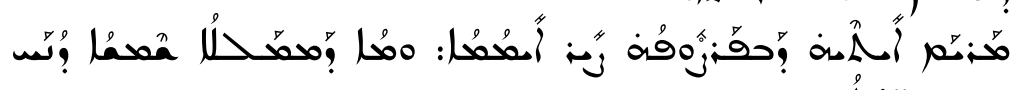

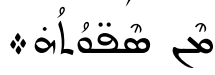

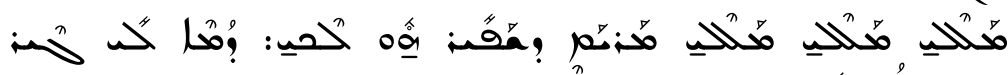

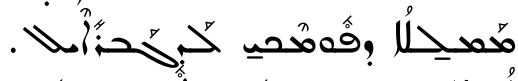

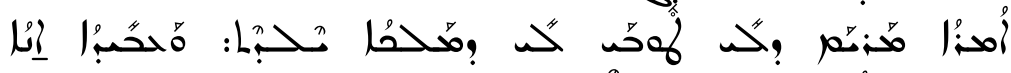

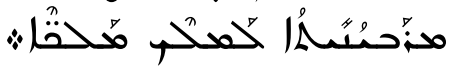

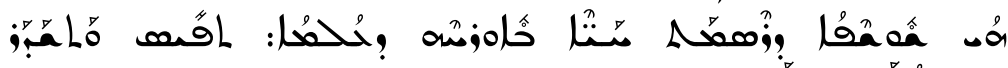

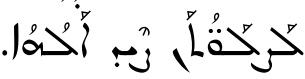




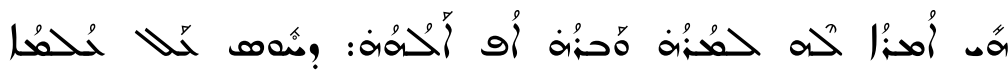
:

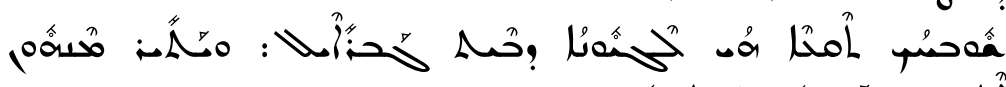

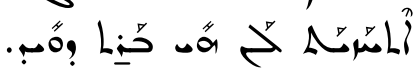

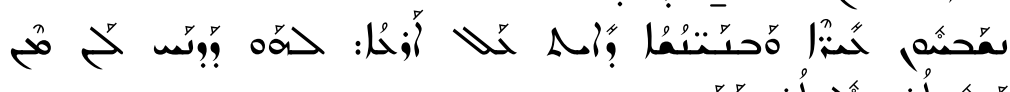
$\star \star \star$

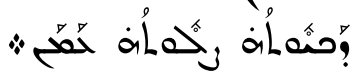

Ş̌́imo, p. 130-131

要

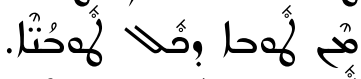

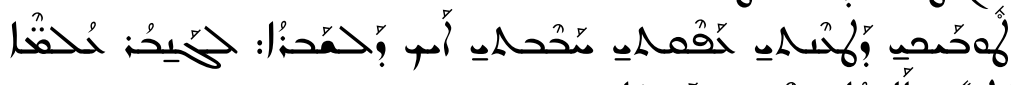

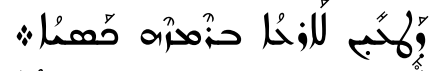

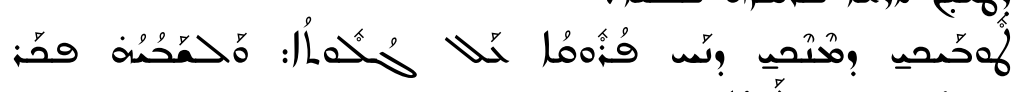
望

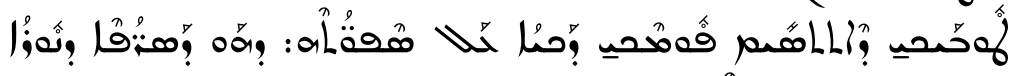

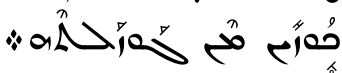

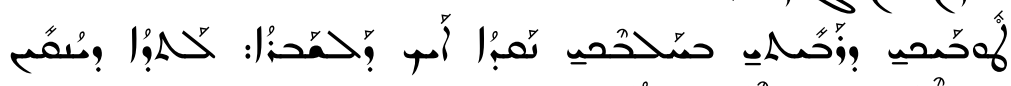

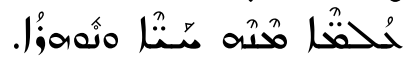

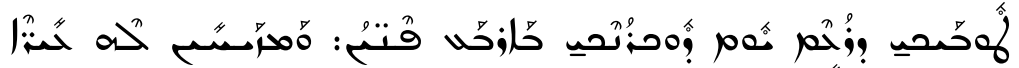

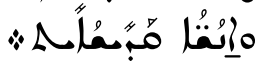

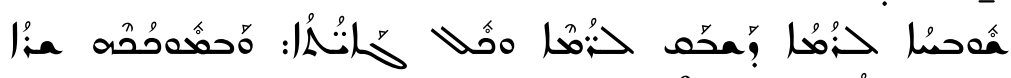

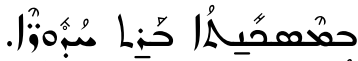

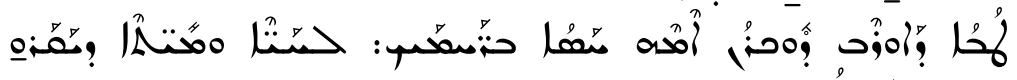
$\star \star \star$

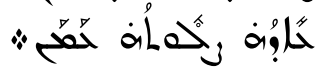

Šḩimo, p. 158-159

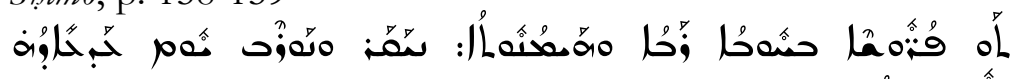
. دُ 


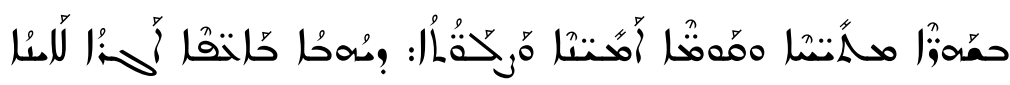

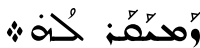

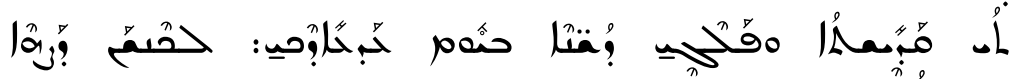

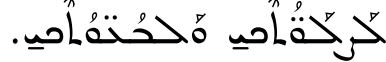

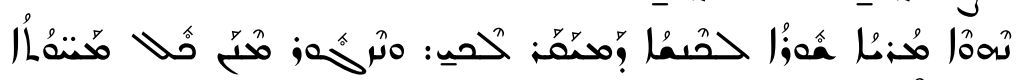

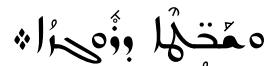

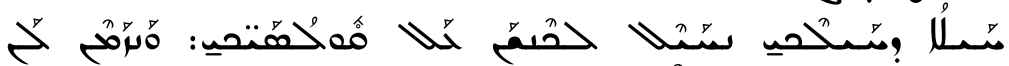

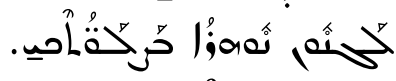

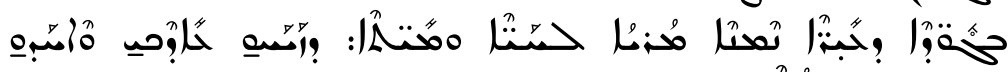

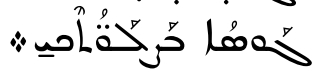

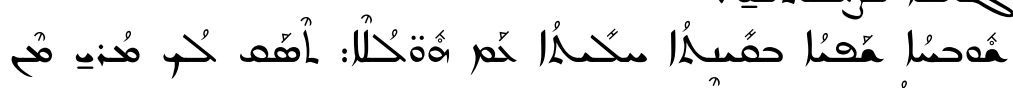

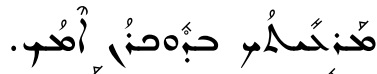

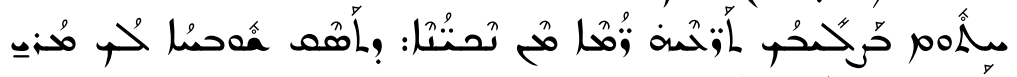

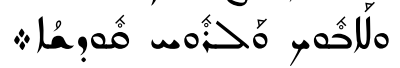

